\title{
Mulemba
}

Revista Angolana de Ciências Sociais

6 (11) | 2016

Políticas, direitos e práticas da sociedade e do Estado

\section{A entronização do soberano de linhagem em Angola: O caso da comunidade Hanya}

The enthronement of the lineage sovereign in Angola: The case of the Hanya community

\section{António Guebe e Domingos Pascoal}

\section{OpenEdition}

\section{Journals}

Edição electrónica

URL: http://journals.openedition.org/mulemba/1542

DOI: $10.4000 /$ mulemba. 1542

ISSN: 2520-0305

Editora

Edições Pedago

Edição impressa

Data de publição: 1 maio 2016

Paginação: 241-267

ISSN: 2182-6471

Refêrencia eletrónica

António Guebe e Domingos Pascoal, «A entronização do soberano de linhagem em Angola: 0 caso da comunidade Hanya», Mulemba [Online], 6 (11) | 2016, posto online no dia 01 outubro 2018, consultado o 26 janeiro 2021. URL: http://journals.openedition.org/mulemba/1542 ; DOI: https://doi.org/10.4000/ mulemba.1542 


\title{
A entronização do soberano «rei» de linhagem em Angola: O caso da comunidade Hanya*
}

\author{
António Guebe $^{* *}$ e Domingos Pascoal ${ }^{* * *}$
}

\begin{abstract}
Resumo: Questões relacionadas com a problemática das autoridades tradicionais têm sido levantadas em vários eventos realizados em Angola. Entendemos que o poder tradicional é uma forma de gestão do poder político, geralmente exercido por uma figura de sucessão por linhagem genealógica, e esse tem sido o costume observado desde há séculos nas sociedades tradicionais africanas, mas não só. Particularmente em Angola, a institucionalização do poder tradicional e o exercício da sua autoridade obedecem a uma forma de organização social fundamentada na linhagem genealógica, podendo ser matrilinear ou patrilinear, porém, hoje, com a tendência para a hegemonia da linhagem patrilinear e isso em virtude do desaparecimento paulatino das sucessões por via materna. Com o recurso à observação directa de trabalhos de campo efectuadas junto da comunidade hanya, a entrevistas aí efectuadas e à análise documental, foi possível obter elementos que entendemos fiáveis, que dão conta da importância do ritual de entronização de um soberano de linhagem, commumente designado «rei», no seio dessa comunidade, um subgrupo étnico Ovimbundu. Este texto visa essencialmente efectuar uma descrição pormenorizada e actual da cerimónia de entronização do soberano «rei» de linhagem na sociedade hanya, proceder à reposição do conhecimento daquilo que no passado contribuiu para a unidade e a coesão interna da mesma sociedade e, através dele, reproduzir conhecimentos susceptíveis de reforçar as políticas do Governo angolano tendentes ao resgate dos valores socioculturais regionais e locais.
\end{abstract}

Palavras-chave: Autoridade tradicional, poder tradicional, genealogias, ritual, rito de passagem, comunidade hanya, populações vahanya, Ovimbundu.

* Comunicação proferida no IV Encontro Internacional de História de Angola, que teve lugar em Luanda no período de 28 de Setembro a 01 de Outubro de 2010, organizado pelo Arquivo Histórico de Angola (AHA), um organismo do Ministério da Cultura (mincult).

** Historiador, Professor Auxiliar do Departamento de História (DH) da Faculdade de Ciências Sociais (FCS) da Universidade Agostinho Neto (UAN) e Doutorando em Estudos Africanos pelo Instituto Superior de Ciências do Trabalho e da Empresa (ISCTE), Lisboa, Portugal.

*** Historiador, Professor Associado do Instituto Superior de Ciências da Educação (ISCED) do Lubango, Huíla e Doutorando em História contemporânea pela Universidade de Évora, Évora, Portugal. 


\section{Introdução}

A questão de entronização do soberano «rei» de linhagem, em geral em África e em Angola em particular, é um processo que sempre esteve associado à organização das sociedades humanas. Os homens ao colectivizarem-se criaram normas ou padrões de comportamento que serviram e servem ainda hoje de linha de orientação do colectivo ou do grupo e, para o cumprimento e preservação destas, instituíram um tipo de poder confiado a uma autoridade tradicional $^{1}$ soberana, cuja designação varia em função das línguas faladas numa determinada região, sociedade ou grupo étnico. Por exemplo, no grupo étnico Ovimbundu, ${ }^{2}$ onde estão enquadradas as populações vahanya, ${ }^{3}$ esta figura de chefe é designada por osoma (plural: olosoma). ${ }^{4}$

1 O conceito de autoridade tradicional carece ainda de estudo aturado, sério, devido ao facto de existirem ainda diferentes experiências subordinadas às diferentes perspectivas, tais como: a consagração de um «rei» por um ritual tradicional, que indica a transferência do poder pelos antepassados para as novas lideranças, pelo que, o zelo e o respeito podem não estar necessariamente relacionados a pessoa humana mas aos antepassados. Daí que o vínculo não esteja necessariamente implicado com o homem, mas à expressão ritual das crenças locais, nas quais se observa a obediência às crenças ancestrais. Entretanto, com o andar dos anos, surgiram múltiplicas experiências das vivências que decorrem da instrumentalização das autoridades tradicionais pelo governo colonial. Esta perspectiva reconhece que a verdadeira autoridade tradicional perdeu as suas raízes, devido às manobras colonialistas (MASsuanganhe 2011: 135), não obstante o articulado da lei que prescreve o que se segue: «As autoridades tradicionais são entidades que personificam e exercem o poder no seio da respectiva organização político-comunitária tradicional, de acordo com os valores e normas consuetudinários e no respeito pela Constituição e pela lei» (REPÚBLICA DE ANGOLA 2010: 85).

2 Comunidade étnica Bantu que habita o Planalto central, compreendendo hoje administrativamente as províncias do Huambo, Bié, Benguela, parte norte da Província da Huíla e parte sul da província do Kwanza Sul.

3 Povo Bantu que, segundo Hauenstein (1967: 7), habita parte do território nacional desde a segunda metade do século xvi proveniente do Reino do Ngola, a sul do rio Kwanza. Inseridos como um subgrupo da grande comunidade étnica Ovimbundu (Lima 1964: 188; RedinHa 1974: 23). Ocupa o espaço territorial que compreende o Centro-Oeste de Angola, que se estende por toda a extensão administrativa dos municípios do Cubal, de Caimbambo e partes norte do município do Chongoroi e sul do município da Nganda, todos pertencentes à Província de Benguela e parte Oeste do município de Kalukembe, da província da Huíla.

4 Termo usado para designar a autoridade tradicional, e que foi aportuguesado pela colonização para «soba». No entanto, convém desde já que este assunto fique esclarecido, sem contudo ser possível dar uma explicação lógica, senão aquela de amalgamar os conhecimentos, o colonialismo português passou a 
No passado colonial, esta autoridade que advém da linhagem foi suplantada, extinta ou remetida ao silêncio e, em sua substituição, foram criadas, no interesse do colonizador, outras «autoridades tradicionais» estruturadas em «soba», «regedor», «seculo»e «milinho» (meirinho?), contra a vontade dos próprios africanos e sem a possibilidade destes contrariar os desígnios que, desde longa data, lhes foram paulatinamente imposto pela administração colonial. Entretanto, com as independências dos estados africanos que começaram a ocorrer sobretudo na década de 1960, salvo raras excepções, a questão da autoridade tradicional de linhagem e da sua entronização, na maioria dos casos, continuou a ser ofuscada pelas novas autoridades políticas e administrativas. E o território de Angola não foi uma excepção quanto ao tratamento de exclusão que se veio a dar às autoridades tradicionais, no período pós-independência deste país, razão que nos leva a trazermos para este debate o tema em apreço.

O nosso propósito visa dar a conhecer a importância que a comunidade hyanya dá a entronização do seu soberano no âmbito do seu sistema de descendência, que, tal como já o dissemos, ocorre no âmbito da linhagem, e isso com vista a reposição dos seus valores culturais e identitários. Para a objectivação de tais propósitos, seleccionamos os métodos e as técnicas que melhor nos parecem se adequar à natureza do estudo pretendido. Para o caso em questão, privilegiamos a forma de raciocínio e de argumentação, cuja abordagem parte do fenómeno conhecido e visa testar as teorias existentes; o estudo fundamenta-se igualmente numa abordagem que parte do geral para o particular (SousA e BAPTISTA 2012: 56). Como técnicas, a análise documental constitui o ponto de partida para o estudo em causa, permitindo o estabelecimento do estado da arte, através do acesso e da análise de fontes primárias e secundárias existentes, complementado com as entrevistas semidirigidas ${ }^{5} \mathrm{e}$ observação directa. O recurso aos instrumentos como o gravador e a

designar o chefe dessas comunidades tradicionais de Angola por «soba», o que entendemos ser um erro crasso, porquanto, esse designativo é uma palavra da língua kimbundu, uma das línguas que é falada em Angola, e ela representa só e apenas o sistema de significação e de representações dessa própria comunidade étnica.

5 Entende-se por entrevista o encontro frente-a-frente de pessoas com vista indagar algo sobre um determinado assunto. É, portanto, uma técnica de interacção 
câmara fotográfica permitiu o registo das intervenções dos entrevistados e a captação de imagens que completam o presente trabalho.

\section{O contexto histórico do poder tradicional vahanya}

Não se pode fazer uma abordagem do poder tradicional de linhagem sem se ter em conta o passado histórico que contempla a existência da Ombala. ${ }^{6}$ O poder tradicional dos Vanhanya tem ligação com as olombala de Ngumbe, de Ngandu, de Mbongo e de Civonga. O enfoque deste estudo está sobretudo direccionado para a ombala de Civonga e seu prolongamento à ombala de Kayimbambu-Taka, por ser a mais antiga de todas. Surge com a migração dos Vahanya como expansão do reino do Ndongo, transpondo o rio Kwanza e rumando em direcção ao sul, por volta de 1671, e serve de ponto de referência para o surgimento das demais olombala, acima referidas (HAUENSTEIN 1967: 229).

A ombala da Chivonga, tal como descreve Hauenstein (1967: 230-234), estava anteriormente localizada na montanha de Ciyokayoka sob liderança de uma soberana, de nome Evangavanga, cujos símbolos do poder «alunga» foram trazidos dos Ngangela (vide fotografia n. ${ }^{0}$ 1)..$^{7}$ Sucedeu à soberana Evangavanga o soberano Mwêlêhombo ka Savi Ocipa, sendo que foi no seu reinado em que os Vahanya atravessam o rio Catumbela e se instalaram na planície da Cimbowa ou Chimboa, na base da montanha Lungu. Nessa altura, essa região

humana que pode variar desde uma simples conversa àquela cuidadosamente pré-definida e sistematizada com perguntas e respostas expostas num roteiro de entrevista (MANN 1983: 99). E, por entrevista simidirigida, como uma das variantes da entrevista, a mais usual na investigação de questões sociais, caracteriza-se pelo facto de não ser aberta e não abarcar um número elevado de perguntas como o inquérito. Permite que o entrevistado se expresse por suas palavras e pela organização e ordenamento dos materiais na forma que desejar, cabendo ao investigador apenas o encaminhamento das suas intervenções no interesse da pesquisa (Quivy 1998: 192).

6 Singular de olombala, capital do reino, onde se situa a residência oficial do soberano, «rei» ou osoma.

7 Comunidade étnica Bantu, localizada no território que compreende hoje as províncias da do Kwandu-Kuvangu, do Moxico e partes da Huíla e do Bié (REDINHA 1974: 24). 
era habitada pelos Vandombe. ${ }^{\mathbf{8}}$ Ao soberano Muẽlẽhombo sucedeu Kandundi Kacikuta que, por sua vez, foi sucedido pelo soberano Kadundi Kovota, «o guerreiro», e Njinga Yonganga Kalunga Kiñali, «o feiticeiro», sucederia no trono o soberano Kandundi Kovota. Por sua vez, o soberano Njinga Yoganga foi sucedido pelo soberano Kandundi Kambondombondo usika oñoma kosi yovava epanda lioñoma ba kalitepa.

\section{Fotografia n. ${ }^{\circ}$ 1. Alunga, símbolo do poder dos Vahanya, trazido dos Vangangela}

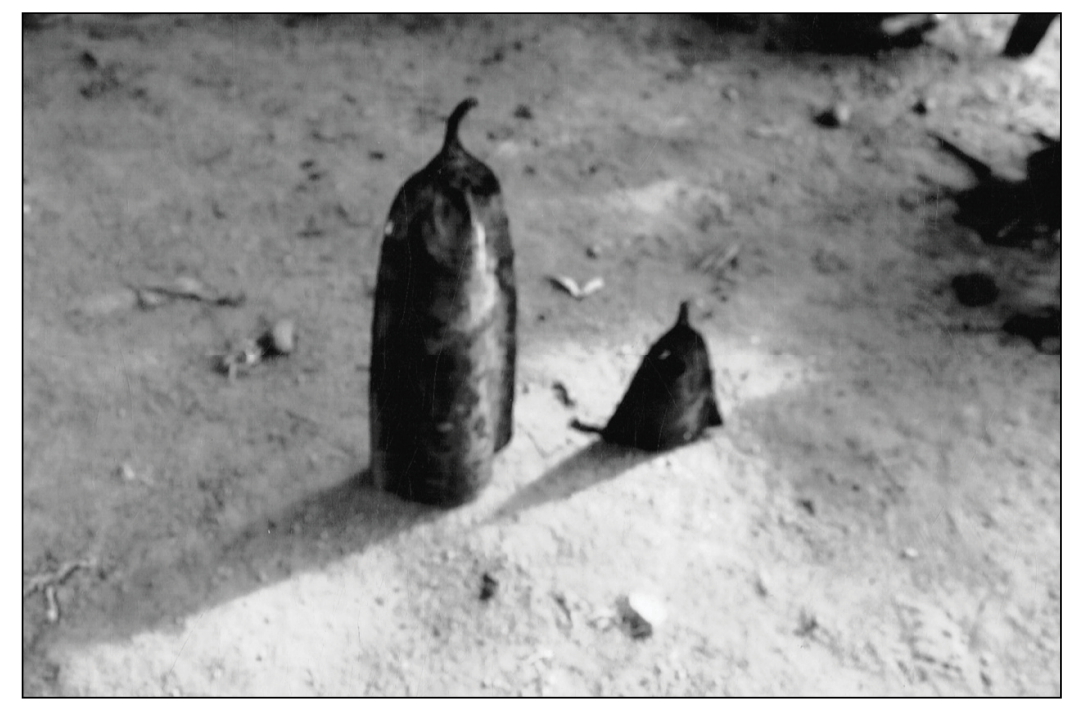

Fonte: António Guebe

Ao soberano Kandundi Kambondombondo sucede o soberano Njinga ya Ndumbu (Njinga Leão) que, por sua vez, foi sucedido pelo soberano Tutuvili, embora, as fontes orais admitam que o sucessor de Njinga ya Ndumbu tenha sido Ngandu Kapuka e não Tutuvili. A verdade, porém, é que com a subida ao trono do soberano Tutuvili dá-se início a sua própria dinastia e foi o mesmo soberano que travou a guerra com o soberano do Mbalundu (Bailundo) Ekwikwi I, quando este último, sem intenção de atacar o primeiro, já que era seu objectivo fazer incursões para o território dos VaHumbi à procura de gado e de escravos. Dessa guerra, saiu vitorioso Ekwikwi

8 Subgrupo da comunidade étnica Ovimbundu, localizado na parte sudeste da Província de Benguela (Redinha 1974: 23). 
I soberano do Mbalundu, e, por este facto, os Vahanya Civonga retiraram-se da região e fixaram-se noutra região, em Ngandu. Foi também no mandato do soberano Tutuvili que os Vandombe se vão retirar da região de Cimbowa por causa de uma epidemia que assolou a área.

Ainda, segundo fontes orais, consta que o soberano Ngandu Kapuka ao assumir, novamente, o poder, abandonou a ombala Ndimba do Civonga, e instalou-se na região de Lutira Wemba, e isso motivado pelas condições que o território oferecia, isto é, as férteis margens dos rios Kupololo (Cuporolo) e Lutira, extraordinariamente propícias à agricultura (vide fotografia n. ${ }^{0} 2$ ).

\section{Fotografia n. ${ }^{\circ}$ 2. As terras férteis de Lutira Wemba, território hanya}

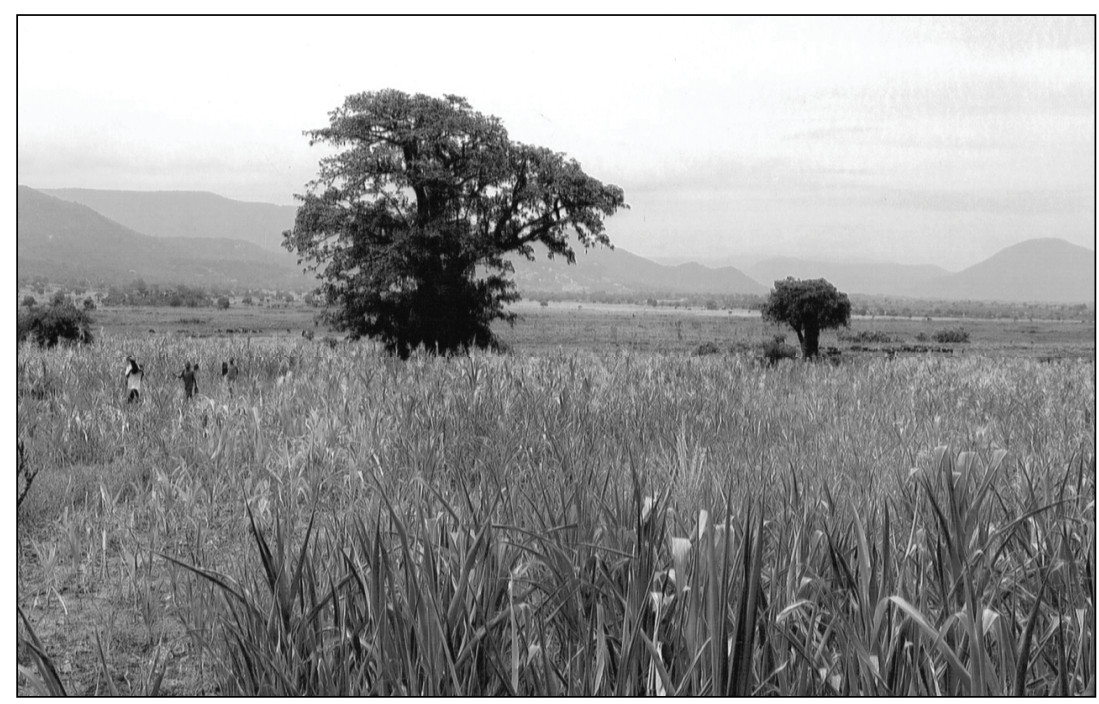

Fonte: António Guebe

Tutuvili morreu sem deixar um sucessor ao trono, originando a 246 observância de um intervalo longo sem soberano. Mais tarde, surgiu então a partir da família antiga de Civonga o seu sucessor, de nome Sikendwa. ${ }^{9}$ Com a morte do soberano Sikendwa sucede-lhe

9 Em língua umbundu significa não posso ser enterrado. Com base em fontes orais, Sikendwa é o nome que lhe foi atribuído devido ao facto de ele mesmo ter dito que teke ndiha sikakendwe lovalã sanga dikalimalima, ou seja, «quando eu morrer, não me enterrem com os intestinos, para eu não trabalhar lá aonde for, ou seja, para eu não me alimentar». E foi cumprida a sua 
ao trono o soberano Njinga Kalumbamba que fora amigo de Ngandu Kapuka, mas que, no entanto, não pertencia à linhagem real; era apenas uma figura notável da família de Ngola. ${ }^{\mathbf{1 0}}$ Foi conduzido da sua terra natal para o reino, ao som da trombeta e dos instrumentos musicais locais (ocisumba, ${ }^{11}$ ocisanji, ${ }^{12}$ e oñoma, ${ }^{13}$ ) onde foi entronizado como novo soberano (vide fotografias n. ${ }^{\text {os }} 3,4,5$ e 6).

exigência. As fontes orais admitem que o sucessor do soberano Tutuvili tenha sido Ngandu Kapuka, indivíduo que abandonou o poder devido a guerras ocorridas entre reinos, em vez de Sikendwa como refere Alfred Hauenstein (cf. Hauenstein 1967: 233). Daí a ligação do seu nome Ngandu com a região onde se instalou a ombala Civonga.

10 Vangola ou Ngola são povos ovimbundu localizados na Comuna de Ngola, Município de Kalukembe, Província da Huíla (Hauenstein 1967: 233).

${ }^{11}$ Espécies de guitarra formada a partir de uma longa caixa esculpida a partir de um pedaço de tronco de madeira upepe, ombovo e ongengelunda. A parte superior é fechada com uma placa com uma abertura ao meio, chamada de onjumbu. Na extremidade oposta à parte aberta estão colocadas cinco varas curvadas de onamba, designadas olombinga, isto é, "chifres», onde estão presas as cordas esticadas para a extremidade oposta da placa que forma a tampa do ocisumba. É tocado exclusivamente por homens, principalmente por criadores de gado bovino, na festa de ocitamba. Ocisumba é, também, tocado pelo proprietário, à noite, depois dos trabalhos para okusocolola, «repensar» os seus antepassados. Enfim, ocisumba é considerado um instrumento da nobreza (HAUENSTEIN 1967: 220).

12 É o único instrumento musical que é revestido de metal em determinadas partes; trata-se de uma espécie de pequeno piano nativo da África Central. Ocisanji é uma placa a qual está ligada uma armação de metal ajustada a um suporte trincheira, ou cavalete de madeira. É um instrumento musical avançado, rico em possibilidades de expressão, que é originário dos Tucokwe ou dos Vangangela, tocado à noite, em casa, ou à volta de uma fogueira. A sua música expressa saudade e amor (HAUENSTEIN 1967: 225).

13 Trata-se do instrumento mais comum em África; é formado de uma parte do tronco de árvore osese (Cassia angolensis Welw), uvanje (Afzelia cuanzensis Welw) e upepe, tendo uma abertura onde se estica a pele de cabra ou de olusenge (Varanus niloticus) esticada para o tronco e presa por alguns pequenos pregos de madeira. Às vezes, o oñoma é totalmente revestido de pele amarrada com fitas extraídas da própria pele. Para emitir o som vibrante, coloca-se no centro da pele da abertura uma massa chamada owaso. Mede feralmente 65,5 de altura e 19,5 de diâmetro. Para tocar oñoma prende-se o mesmo entre as coxas, sendo tocado com as duas mãos, depois da sua pele ser previamente aquecida ao lume. Os Vahanya gostam de tocar oñoma acompanhado de um outro oñoma mais pequeno denominado ocikenjengo, que serve para fazer mistura da música. E um instrumento religioso por excelência, tocado em várias cerimónias, festas, tratamento tradicional, etc. (HAUENSTEIN 1967: 225-226). 
Fotografia n. ${ }^{\circ}$ 3. Ancião Silva Kakanda tocando ocisumba, um tipo de instrumento musical vahanya

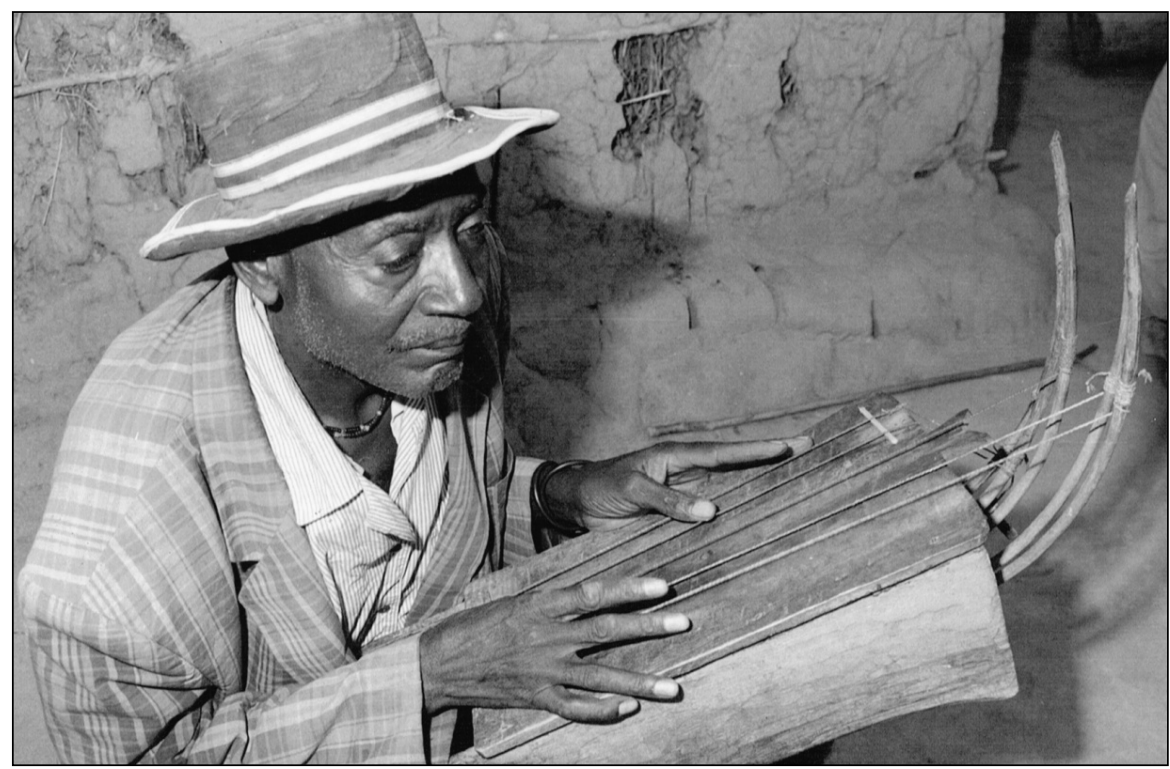

Fonte: António Guebe

Fotografia n. ${ }^{\circ}$ 4. Ocisanji, um tipo de instrumento musical dos Vahanya

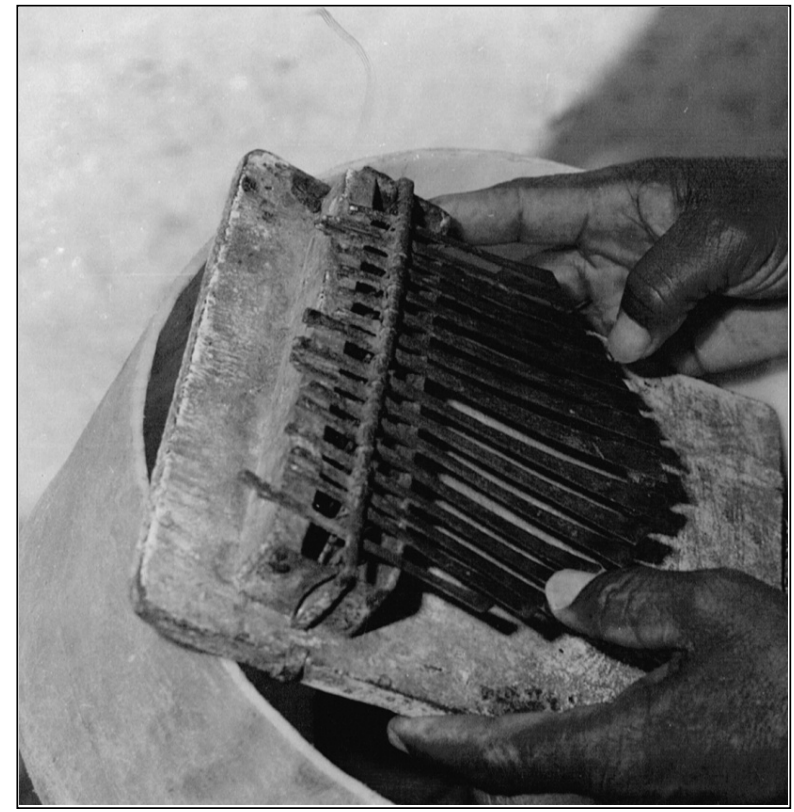

Fonte: António Guebe 
Fotografia n..$^{\circ}$. Oñoma, «tambor», «batuque», de José Kacivela, famoso tocador da comunidade vahanya

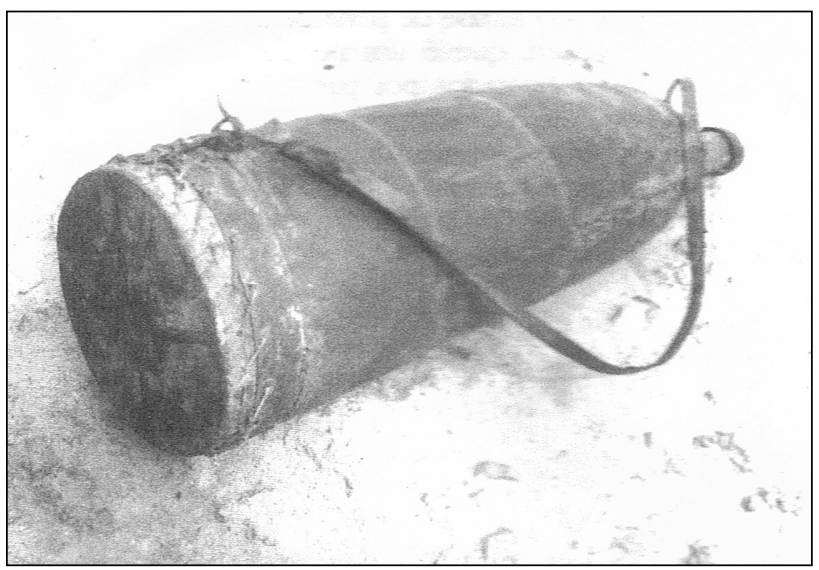

Fonte: Guebe (2003: 91)

Fotografia n. ${ }^{\circ}$ 6. José Kacivela (falecido a 20 de Outubro de 20o8) e seu oñoma, ou «batuque», preso entre as coxas, vibrando com a comunidade vahanya

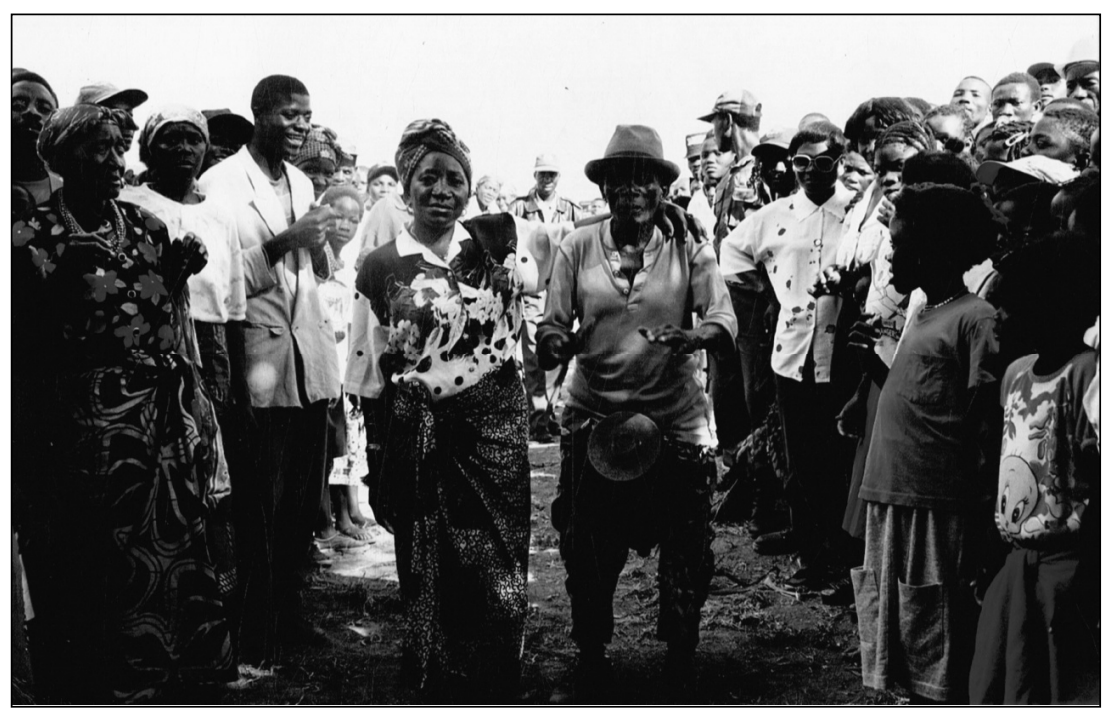

Fonte: António Guebe

Para a sua segurança, devido às ameaças das guerras entre dignitários, o soberano Njinga Kalumbamba orientou que se procurasse, através dos caçadores de elefantes, um lugar de segurança para instalar a ombala, tendo obtido a confirmação da existência 
de grutas num lugar situado bem no cimo da montanha Ndimba, com cerca de 1.470 metros de altitude, grutas essas que ofereciam segurança para o novo soberano e sua comitiva. Assim, o soberano Njinga Kalumbamba e seu séquito dirigiram-se para essa região transpondo o rio Kupololo, onde, na margem esquerda do referido rio, depois de terem efectuado alguns disparos com armas de fogo, acabaram por aí se instalar. Com efeito, foram encontradas muitas cavernas e cavidades, tidas como ideais para a instalação de uma nova ombala Civonga (vide fotografias n. ${ }^{\text {os }} 7,8$, 9 e 10). No entanto, após a instalação geral na referida localidade, o soberano Njinga Kalumbamba enfrenta um pretendente ao trono, de nome Ngandu Kapuka que, depois de ter ido ao Ndombe (terra de feitiço), a partir da região de Ngandu antiga, ombala Civonga, preparou uma revolta que, após ter feito cinco disparos de arma do fogo, destronou o soberano Njinga Kalumbamba. Não tendo tempo para se defender, considerou o acto de traição, fugiu para a terra natal Ngola Kalukembe $^{14}$ (HAuENSTEIN 1967: 233-234).

Fotografia n..$^{\circ}$. Cavernas e cavidades da montanha Ndimba, lugar da antiga Ombala de Civonga

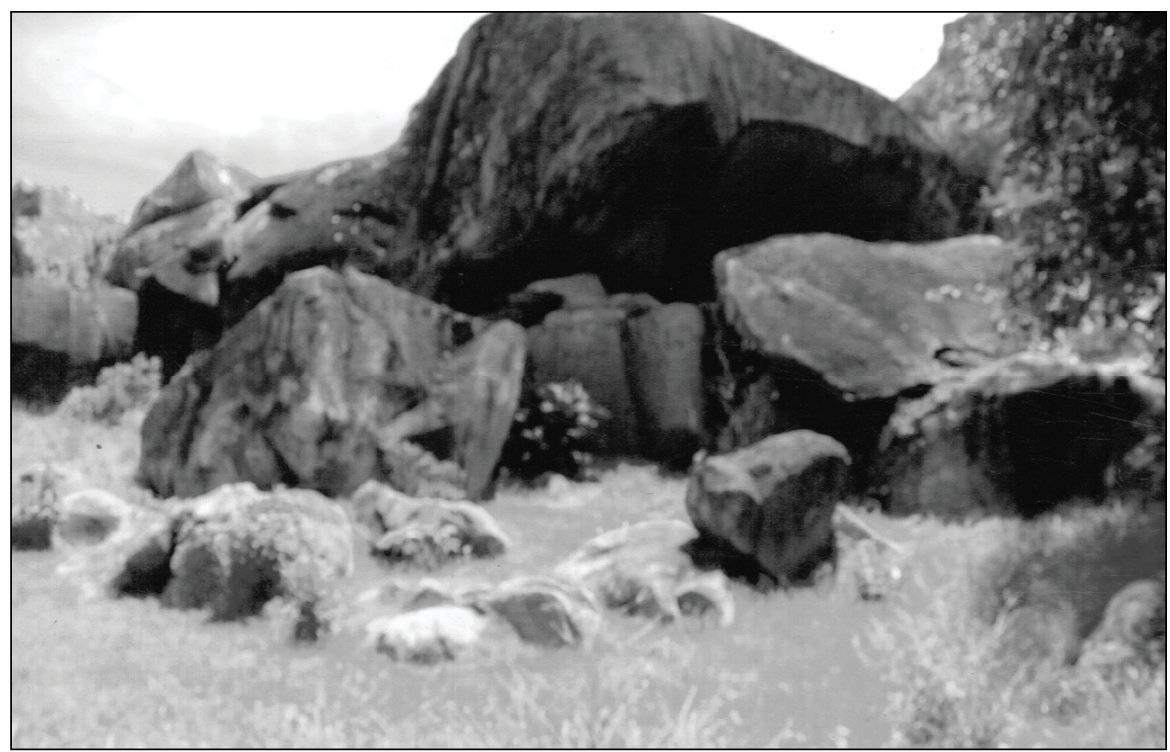

Fonte: António Guebe

${ }^{14}$ Fontes orais referem que Njinga Kalumbamba, ao deixar o reino, expressou as seguintes palavras: Inana okambanzela kohombo, ame ndahinda, o que quer dizer, «É a Nana [supõe tratar-se da esposa] que me vai procurar no Kohombo, fui.» 
Fotografia n.o 8. Primeira caverna de vigilância para o acesso a Embala Civonga

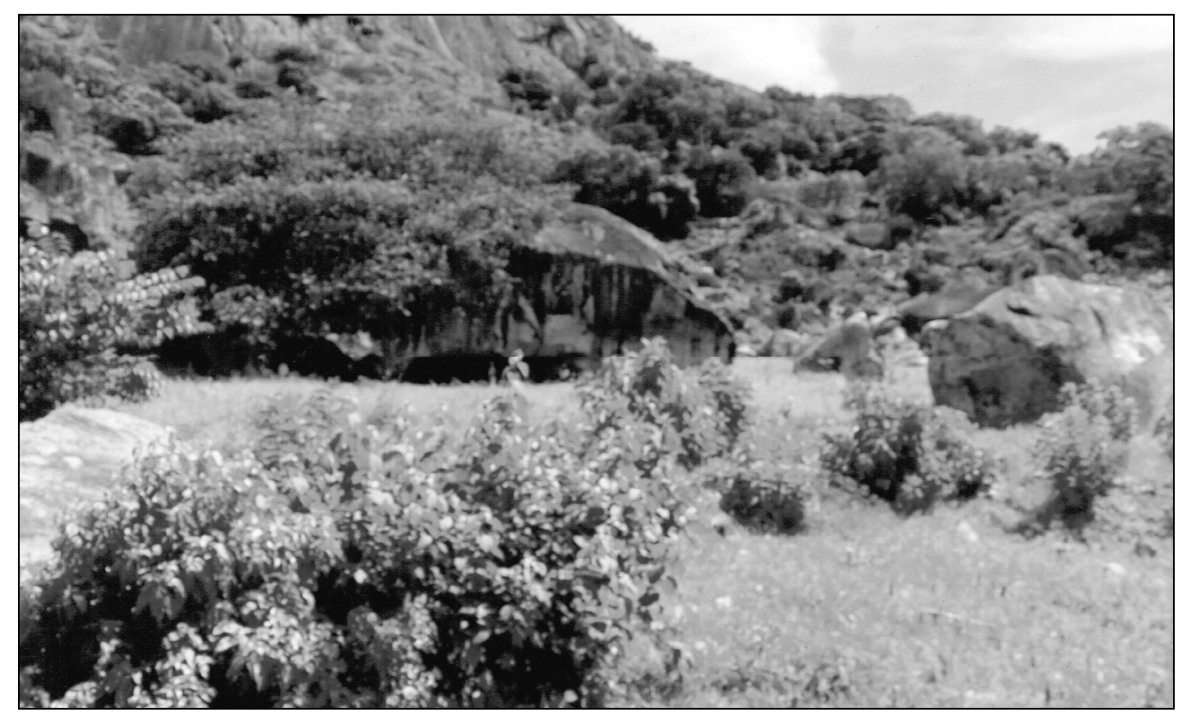

Fonte: António Guebe

Fotografia n. ${ }^{\circ}$ 9. Cimo da montanha Ndimba, que serviu de vigilância para o acesso a Ombala Civonga

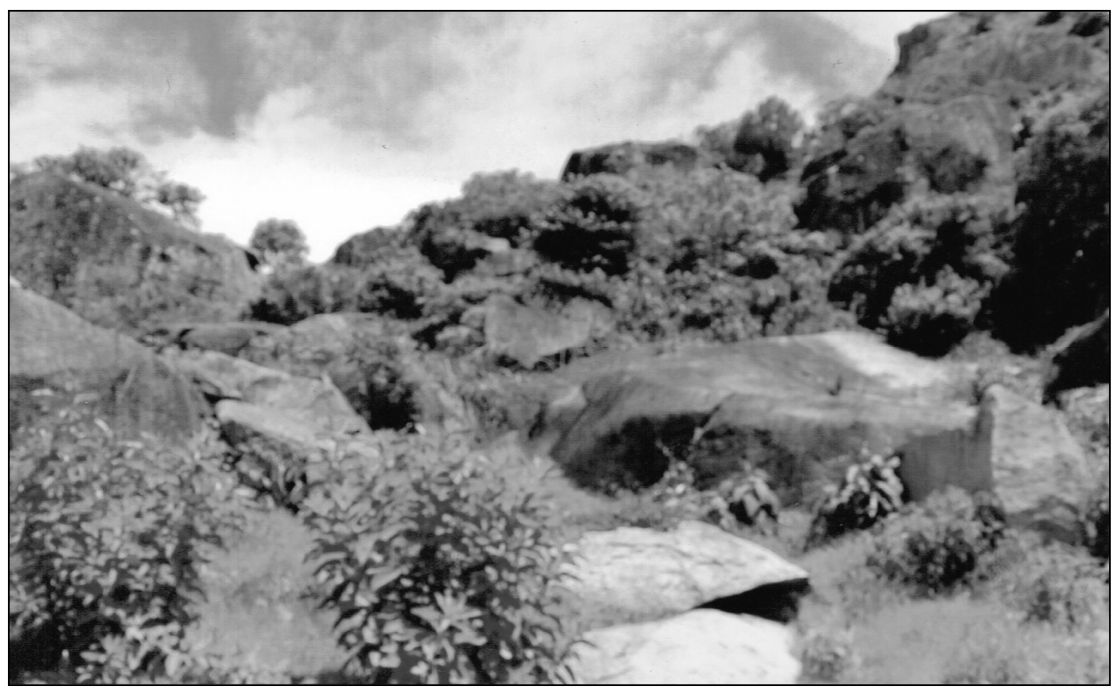

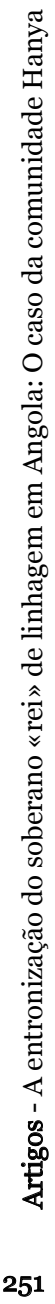

Fonte: António Guebe 


\section{Fotografia n..$^{0}$ 10. Caverna residência real,}

Ombala Civonga, montanha Ndimba

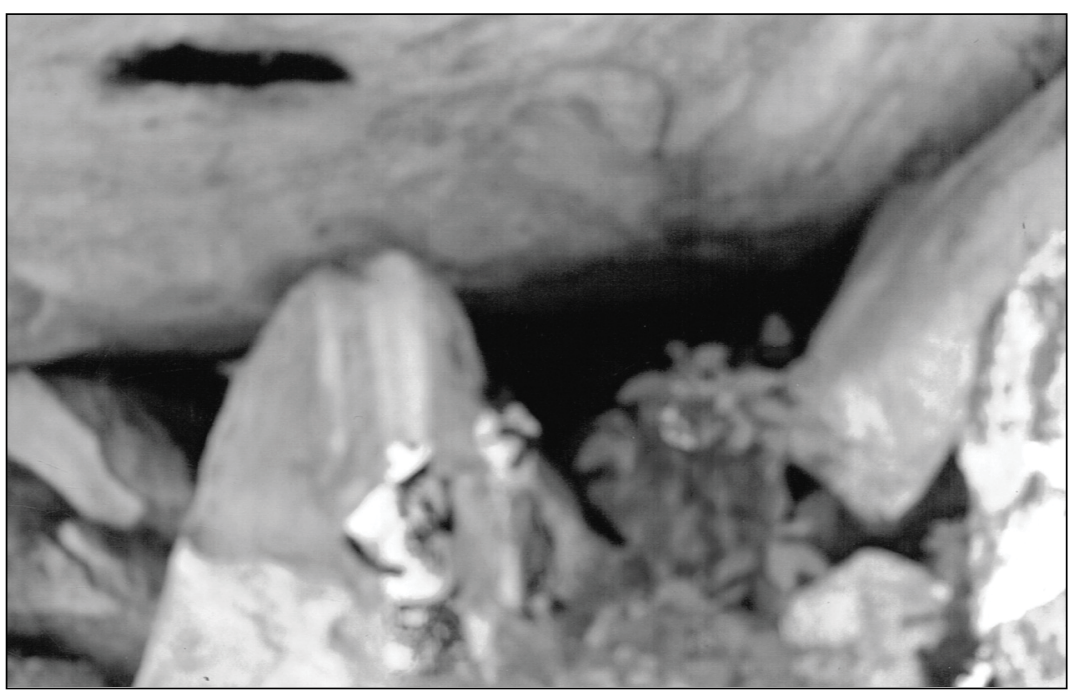

Fonte: António Guebe

Ngandu Kapuka, o revoltoso, segundo o mesmo autor, torna-se soberano da ombala Chivonga, toma o poder e passa a reinar com o título de Ngandu Kapuka katundimbula kasila kwapwa, que significa «Eu sou o verme, o último remanescente de mel depois que os raios foram removidos». Mais tarde, alcunhou-se com outro título Ame [lya] ekunya Nana Katindi, que quer dizer: «Eu sou o bezerro, o melhor e mais forte da minha mãe Nana Katindi».

Ngandu Kapuka morre em 1906 e com ele termina a dinastia dos soberanos vyandundumba («reis do feitiço»). Sucedeu-lhe Sindula, que reinou até 1921, sendo o soberano que vai assistir ao controlo do reino pelas autoridades portuguesas, e que vai proceder à eliminação de muitos ritos até aí observáveis (como os da entronização dos olosoma Vyandundumba). ${ }^{\mathbf{1 5}}$

Com a retirada do soberano, a ombala de Civonga deixa de exercer o poder central do reino, tendo sido essa função transferida para a ombala de Lutira Wemba, exactamente na localidade de Tavela. Hoje a ombala da Civonga encontra-se localizada no sopé das

15 Um tipo de «reis» que, no passado, foram temidos pelo feitiço que ostentavam. Os seus movimentos eram acompanhados com batuques. 
montanhas de Citunga, Yanga, Kalima, Palanga e Ekelenge. Ao soberano Ngandu Kapuka sucede-lhe Sambu que assistiu a chegada dos europeus.

Com a morte do soberano Sambu, em 1921, o poder passou para o soberano Kolovolo, ${ }^{\mathbf{1 6}}$ quem repartiu a ombala em duas: a primeira ombala de Lutira Wemba localizava-se na mesma área, e a segunda ombala localizava-se na localidade de Kalumwe. Na ombala de Lutira Wemba, o soberano Kolovolo vai reinar de 1921 a 1940. Depois da morte sucede-lhe o soberano Njinga, tendo reinado de 1940 a 1943. Depois da morte de Njinga, subiu ao trono Sindula que reina de 1943 a 1955, sucedido após a morte por Kanjamba ${ }^{17}$ que reina apenas um ano de 1955 a 1956, sucede-lhe Foloti que, também, vai reinar apenas por algum tempo do ano de $1956 .^{\mathbf{1 8}}$

Ao soberano Foloti sucede Ndaka que reinou de 1956 a 1957. A morte do soberano Ndaka deu lugar à sucessão do soberano Mbunju, que reina de 1957 a 1959, destituído pela autoridade colonial portuguesa, devido a pressão dos comerciantes da região que preferiam um soba letrado, tendo sido indicado José Pedro ou, simplesmente, Petulu, então ajudante do soberano Mbunju, que termina assim a linhagem Kolovolo e reina com o título de «soba», de 1959 a 1980 (HAUENSTEIN 1967: 233).

Consta das fontes orais que o soberano Sindula fora da linhagem de Kolovolo, tendo abandonado o poder por ter cometido homicídio. ${ }^{19}$ Consta, de igual modo, que o soberano Foloti abandonou o trono por temer represália do governo colonial, devido a fuga dos súbditos ao pagamento de imposto. Sobe ao poder Mbunju, que não era da linhagem de Kolovolo e que vai reinar sob pressão dos

16 Consta das fontes orais que foi durante o reinado deste rei que foi aprisionado o primeiro comerciante europeu que tentou a aproximação com o reinado, tendo sido liberto graças à astúcia do místico Kaluvundu, ajudante do rei e dos disparos efectuados por um outro comerciante que saíra em seu socorro.

17 Pouco falado na tradição oral, supõe tratar-se de um indivíduo que não seja da linhagem, admitindo-se mesmo a existência de antecedentes de escravatura, um facto que as fontes orais não revelam.

18 De acordo com as fontes orais este soberano abandonou o poder por temer o castigo das autoridades coloniais, devido a falta de pagamento de imposto de alguns dos seus súbditos.

19 Quando castigava um insubmisso até à morte por rejeitar o pagamento de imposto geral mínimo. Quis Sindula escapar-se do castigo prometido pela administração colonial, devido aos antecedentes de falta de pagamento no seu reino. 
comerciantes brancos que preferiam um «soba» letrado, facto que justifica o aparecimento de José Pedro ou simplesmente Petulu, então ajudante do soberano. A partir desse episódio, deixou-se de se efectuar a entronização dos soberanos de linhagem.

Com a subida de Petulu ao poder quebra-se a sucessão por linhagem. Foi durante o seu reinado que o território da Lutira Wemba conheceu a guerra entre o Movimento Popular de Libertação de Angola (MPLA) e a União Nacional para a Independência Total de Angola (UNITA), no período pós-independente do país, isto é, na década 1980 do século passado. A sua morte abre a continuidade da linhagem Kolovolo. Subiu ao trono Marcos Ndambuka, filho de Njinga, quem exerce o duplo poder governamental e tradicional, até à sua morte, por doença, em 2009. Em sua substituição, foi entronizado em 2010 o actual soberano, seu filho Paulo Marcos. ${ }^{20}$

Actualmente, em termos funcionais, o soberano Paulo Marcos como «soba» da ombala Tavela, capital do reino, depende do regedor da povoação Filipe Jongo Elawu. Este, por sua vez, depende do regedor comunal da Capupa que se subordina ao regedor municipal do Cubal que, por sua vez, depende da central provincial (Benguela). Como podemos aqui observar, o rei vive numa situação muito embaraçosa pelo facto de se ter convertido em «soba» e estar sob a dependência de regedores, o que lhe esvazia todos os seus poderes políticos, religioso, socio-económicos e administrativos.

A nova ombala de Kalumwe, desintegrada da ombala de Lutira Wemba, foi reinada por Cimbyongo, sucedido por Civela e depois por Cilandula que assistiu à proclamação da Independência.

No akôkôto (cemitério dos soberanos), localizado na antiga ombala de Ndimba Civonga, estavam guardados cinco crânios, lembrando-se apenas de quatro dos soberanos Ngandu, Kandunda Kacikuta, Tutuvili, Njinga ya Ndumbu e Kandunda II. Destes, quatro foram queimados por ordem do missionário destacado na missão Evangélica da Kaswa, Alfred Hauenstein, na década de 1960 do século passado, com a conivência do hanya Lino Kanjelela, que levou Haunstein a visitar a antiga ombala Ndimba de

\footnotetext{
20 Investido no poder através do ritual de tradição, cujo acto de entronização, o primeiro na região, desde a presença europeia, teve lugar dia 7 de Agosto de 2010, preferindo reinar com o título de Kolovolo II.
} 
Civonga e akôkôto. Com aquela visita, o referido missionário produziu a sua obra com o título: Les Hanya (1967).

Com o andar do tempo, a ombala de Lutira Wemba originária da ombala da Civonga tem estado a crescer, somando actualmenete 16 olombala, nomeadamente; Tavela (a ombala grande ou ombala sede, dirigida pelo soberano de linhagem Paulo Marcos, onde se localiza o regedor da povoação que dirige todas as 16 olombala: Cikelo; Wemba; Canjelela; Chinoñwa; Chitunga; Bulundundu; Cahingolo; Bututule; Cacrewe; Dumbili; Bumbulu-Handa yo Tembo; Kandonga; Kacisamba; Cikala-Conombo; Civonga; e Osuke.

A migração dos povos implica também a «migração» do poder tradicional em muitos povos africanos. Os Vahanya estenderam o seu território com a migração dos povos para Sul, Norte e Oeste, ocupando as localidades dos territórios dos Municípios do Cubal e do Caimbambo e a parte Norte do Município do Chongoroi e Sul da Ganda.

A movimentação migratória dos Vahanya de Caimbambo para a região da Taka-Chongoroi moveu, igualmente, o poder tradicional circunscrito na ombala. A ordem de sucessão compreende: Kongayika Kanumba la Samba, o fundador que foi secundado por Ngele Kapeke Komekome que, por sua vez, cedeu lugar ao Kambundu, que foi substituído por Ngulawa, ${ }^{21}$ que foi deposto pelo colonizador. Este, por sua vez, foi substituído pelo Kaheya que deu lugar a Daniel Branco Prata, assassinado durante o conflito armado pós-independência, tendo sido substituído pelo filho Pedro Kesongo, falecido por acidente de viação e, finalmente, Xavier Tonico. Este último foi investido em cerimónia tradicional ocorrida no dia 4 de Setembro de 2010, e que escolheu o seu nome próprio para reinar.

Algumas fontes orais afirmam que o reinado dos Vahanya tem ligação, quanto à sua origem, com os reinos do Planalto central, nomeadamente de Cingolo, do Mbalundu (Bailundo) e do Wambu (Huambo), o que é provável, uma vez existirem informações segundo as quais as investiduras do poder real dos Vahanya resultam de um mandato de Ngola Kilwanji ka Samba, soberano do reino do Ndongo.

${ }^{21}$ Foi deposto pelo colono por se ter ausentado do soba do durante o tempo achado como excessivo. 


\section{Cerimónia de entronização do soberano de linhagem entre os vahanya}

O poder tradicional e de linhagem em Angola em geral e dos Vahanya em particular conheceu fortes interferências do poder colonial com a substituição de alguns soberanos e o empossamento de outros contra a vontade da população, tal como refere Pascoal (2003:95), ao afirmar que,

«Às vezes, o governo colonial intervinha na sucessão, substituindo os sobas que não lhe mereciam confiança por outros da sua conveniência, como os antigos sipaios, ou ex soldados indígenas, embora estes não fossem da aceitação das populações, por não pertencerem a nenhuma linhagem. As populações aceitavam-nas resignadas mas, no fundo, não as reconheciam como tal, porque para o povo a verdadeira autoridade era aquela que vinha da linhagem. Por isso, havia muitos conflitos entre o verdadeiro soba e o improvisado, pois este, por falta do poder, da feitiçaria e da legitimidade, temia o verdadeiro soba».

Acto continuado no período pós-Independência e, sobretudo, durante o conflito armado, os sobas passaram a ser indicados de acordo com os interesses dos partidos políticos que, no teatro do conflito, controlassem a região.

A entronização de um soberano de linhagem pressupõe a existência de um poder tradicional, cuja ordem de sucessão, tanto pode ser por sistema matrilinear (antigamente), quanto por sistema patrilinear (presentemente). No sistema matrilinear, em caso de vacatura real, é eleito um sobrinho, filho do irmão do soberano defunto ou deposto, segundo a tradição oral, tem a ver com a certeza uterina do filho da irmã. Com a colonização europeia e a presença da Igreja Católica e da Igreja Protestante, este princípio de sucessão foi abolido, dando lugar ao sistema patrilinear, em que o filho ou o irmão do rei cessante é o sucessor ao trono.

A entronização do soberano de linhagem é um rito de passagem, segundo o antropólogo e escritor francês Arnold Van Gennep (1978); e/ou rito de instituição, segundo o sociólogo Pierre Bourdieu (1982). Gennep (1978:101) considera os ritos de passagem 
como actos sucessivos que vão desde o rito de separação do profano, o rito de agregação ao sagrado e ao rito de tomada de posse do mundo divino e terrestre. A adopção do termo rito de passagem, segundo o mesmo autor, tem a ver com o facto de maior parte das sociedades, sobretudo africanas, a vida da pessoa obedecer a uma passagem sucessiva de uma ocupação a outra. Sendo, portanto, o viver que requer a existência de passagens sucessivas de uma sociedade especial a outra, e de uma situação social a outra, de forma que a vida do indivíduo se transforme numa sucessão de fases (GENNEP 1978: 38).

Ainda na perspectiva do mesmo autor, os ritos de passagem apresentam-se em três estágios: de separação, de margem e de agregação. Neste caso em concreto, o da entronização, o primeiro estágio, o de separação, dá-se quando o candidato é eleito para fazer parte da aristocracia. O segundo estágio, o de margem, representa o período em que o candidato deixou a sua vida normal na comunidade, mas ainda não adquiriu uma nova vida ou status. Este estágio é também denominado por Bonte e Izard (1991:631) de «terra de ninguém». E, finalmente, o terceiro estágio, o de agregação, que se verifica com a tomada de posse do novo rei, sinal de ter adquirido o novo status (GENNEP 1978: 38).

Para Bourdieu (1982: 38-39), a entronização do rei de linhagem não faz passar, mas sim, «legitima», «consagra» e institui. Na sua opinião, o que conta não é tanto a passagem de um estado ao outro estado, mas sim a linha de diferença entre dois grupos de indivíduos pré-existentes.

Argumenta que o rito não faz passar mas institui, sanciona, santifica a nova ordem estabelecida, está dotado de poder de consignação estatutária, encoraja o promovido a viver de acordo com os ideais sociais relacionados com a posição em que se encontra. Defende que, por exemplo, os actos de casamento da circuncisão, da concessão de grau ou títulos, da imposição de uma chancela, assinatura ou rubrica a um documento só podem ter o valor que lhes é devido se forem celebrados por instituições reconhecidas a instituir, ou seja, um acto onde todo o grupo se revê, ou que seja praticado por uma instituição reconhecida. Mas, assegura que não existe uma exclusão mútua entre os ritos de passagem e os ritos de instituição, pois admitem existirem um no outro. 


\subsection{Ritual de investidura dos soberanos vahanya de li- nhagem, da Lutira Wemba e da Taka}

Consideram-se os actos de investidura dos soberanos de linhagem realizados nas localidades de Lutira Wemba e da Taka como os primeiros na região e, quiçá, em muitas regiões do país que, desde que se verificou a interferência do poder colonial e da igreja, por um lado, e do menosprezo e da exclusão dos mesmos no período pós--Independência, por outro lado, nunca tiveram lugar investiduras aos poderes tradicionais com rituais.

A investidura ou entronização do novo elombe ou osoma entre os Vahanya decorre da vacatura por morte ou por destituição ou por outras razões justificáveis que podem ser por incapacidade ou outras ainda que podem ser dolosas, cuja continuidade do dignitário rei no poder pode pôr em causa a dignidade do reino. Nos dois reinos de Lutira Wemba e da Taka, a investidura dos novos soberanos decorreu da existência de vagas por morte.

Os rituais tradicionais, na perspectiva de Wilson (1954: 241), revelam os valores culturais no seu nível mais profundo, onde os homens expressam aquilo que os toca mais intensamente. Os valores culturais do grupo são enaltecidos de forma convencional e obrigatória, e a sua preservação depende do conselho de anciãos, representado por uma personalidade ideal - o elombe, que no passado provinha da linhagem materna ou paterna, conforme procedimentos actuais. Uma vez escolhido o candidato pelo conselho de anciãos, segue-se a marcação da data de investidura.

Se a sucessão for por linhagem materna cabe aos da linhagem paterna a investidura do soberano. Se for por linhagem paterna, neste caso, são chamados os da linhagem materna a investir o soberano. $\mathrm{Ou}$ seja, nos membros ou famílias de sangue real há investidores e investidos. Esta situação tem provocado uma espécie de rivalidade conhecida entre os Vahanya de ociñgahi-cove, que significada «seu rival ou inimigo». Segundo explicações de fontes de tradição oral, a razão da existência de duas linhagens a de investidores e de investidos tem a ver com o facto do indivíduo da mesma linhagem ter a ambição de cobiçar o trono e, logo, pode fazer mal (golpear) ao candidato no acto da investidura. Pelo contrário, os da linhagem contrária como não podem ser investidos ao trono não se interessam em golpes.

No dia da investidura, o candidato apurado é levado para o local previamente preparado, onde vestirá a indumentária tradicional e 
cerimonial na presença dos investidores, que são, neste caso, a tia, irmã do pai, e o filho desta, portanto, primo do candidato. A indumentária cerimonial compreende:

a) Um pano branco que envolve a cintura, caindo sobre os pés, conhecido por omaleko. A cor branca simboliza a felicidade, a paz e alegria na comunidade. Aliás, Beattie (1964: 203) considera que, quanto à forma de apresentação, os rituais são representados pelos símbolos ${ }^{22}$ que podem ser instrumentais e/ou expressivos;

b) Um lenço na cabeça, que representa a coroa e simboliza a glória, quer do soberano (elombe), quer do povo;

c) O chapéu representa o poder que o soberano ostenta;

d) As sandálias transmitem a soberania do dignatário (elombe), representando o poder económico e a civilização do soberano. O soberano tem de exibir o poder económico usando sandálias, porque, de contrário, seria visto como homem normal e pobre. Tem de se diferenciar dos demais.

Depois de vestido, o candidato sai do local, onde foi preparado para o local da cerimónia de investidura, completamente tapado com um pano, conduzido pela tia e o primo que o preparam. Por uma questão de respeito, a população não pode saber o local onde é preparado o futuro soberano.

No local da cerimónia, coloca-se uma cadeira especial, que representa o símbolo do poder que usará nas cerimónias, tais como o encontro com os conselheiros e nos julgamentos. A referida cadeira fica posicionada ao lado de uma esteira que reflecte o respeito ao soberano, por cima da qual se estende a pele da onça por onde pisa o entronizado, traduzindo a ira do soberano que supera a ira de qualquer homem conduzido para a ombala, por mais nervoso que seja.

22 Símbolo como sinal compreende qualquer coisa conhecida como tipificador, representador ou lembrador de algo de extrema importância prática, por possuir qualidades semelhantes ou por associação de facto ou pensamento. Envolve objectos, actividades, relações, eventos, e outros sinais. Símbolo fora do contexto de mero sinal apresenta várias interpretações múltiplas, evocando emoções impulsionadoras dos homens a acção. Geralmente ocorrem em padrões estilizados como em rituais, cerimonial, troca de presentes e como vários traços de cultura. Portanto, o comportamento simbólico é um comportamento aprendido, o que implica que cada sociedade e cultura possui seu próprio sistema simbólico (Euzo 1986: 1-7). 
Começa o ritual com o candidato sentado sobre a cadeira especial em cima da qual são colocadas duas folhas de mulembeira cruzadas ou colocadas debaixo dos pés do investido que simboliza a sombra e frescura da mulembeira e a mão pacificadora do soberano. $\mathrm{O}$ investidor dirige-se ao candidato investido e profere as seguintes palavras: Ndikuvyalisa monduko ya kulu, o que quer dizer: «Vou-te investir em nome dos mais velhos», refere-se aos antigos soberanos e cita os seus nomes por ordem de sucessão.

No caso da investidura do soberano (elombe) de Lutiva-Wemba foram citados os seguintes soberanos:

- Ngandu Kapuka;

- Sikendwa;

- Nginga Ye Kamba;

- Tutuvili;

- Njinga Kalumbamba;

- Sambu (todos do período pré-colonal);

- Kolovolo;

- Foloti;

- Njinga;

- Sindula;

- Mbunju; e

- Marcos Ndambuka (retomada a linhagem de Kolovolo, período colonial e pós-independência).

Para o reino da Taka foram referenciados os seguintes soberanos:

- Kongaika Kanumba la Samba;

- Ngele Kapeke Komekome;

- Njilahulu (período pré-colonial);

- Kambundu;

- Ngulawa (deposto pela autoridade colonial);

- Kaheya;

- Daniel Branco Prata; ${ }^{23}$

- Pedro Kesongo ${ }^{24}$ (período colonial e pós-independência).

23 Assassinato durante a guerra pós-independência, no dia 17 de Março de 1993.

${ }^{24}$ Falecido em acidente de viação. 
Após as palavras do investidor, o candidato durante o acto de investidura presta juramento aos antepassados, comprometendo-se a seguir os seus ensinamentos e adopta o nome de um dos reis de sua preferência, ou seja, aquele por quem possui admiração. A adopção do nome não é obrigatória, pois, pode ocorrer o caso do rei investido ter a sua própria preferência na escolha do nome, de acordo com o conhecimento que tiver sobre a história do reino ou reinar com o seu próprio nome.

Fotografia n. ${ }^{\circ}$ 11. Kanjange Tutuvili, autoridade tradicional entre as filhas, portando cassetes apangoti, símbolo do seu poder

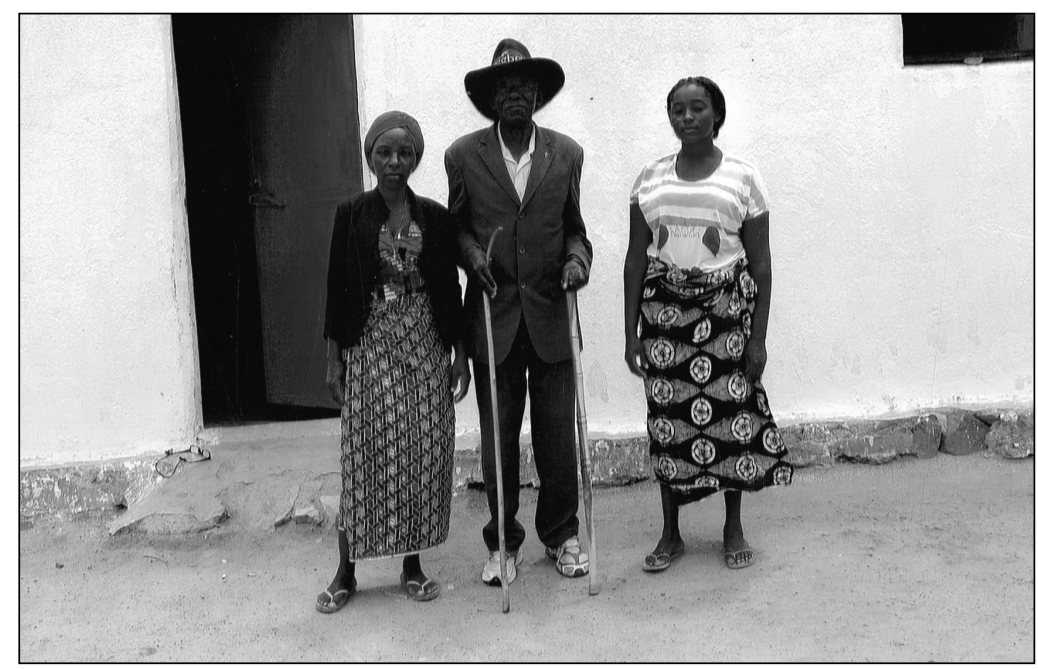

Fonte: António Guebe

Segue-se, então, a entrega dos meios que simbolizam o poder ao soberano investido, como:

1. A bengala, conhecida pelos Vahanya por epangoti, com dois ramos a representar uma árvore de sombra onde as pessoas recorrem como protecção da irradiação solar, ou seja, para o refrescamento. Ela só é usada para os momentos de trabalho da solução dos problemas ou durante os encontros com o seu povo ou nas viagens por se diferenciar dos demais (vide anexo n. ${ }^{\circ} 3.1$ );

2. A arma de repetição «kanhangulu», que representa a defesa e segurança da ombala e do povo surge com as guerras entre os povos naquela época que objectivavam destruir as olombala dos povos vizinhos; 
3. O batuque, que representa a felicidade, a alegria da população pelo som produzido;

4. Ocisumba, ${ }^{25}$ que simboliza a riqueza ostentada pelo dignitário (o gado) e sua gente;

5. Os utensílios de uso pessoal, tais como: pratos e canecas, de-

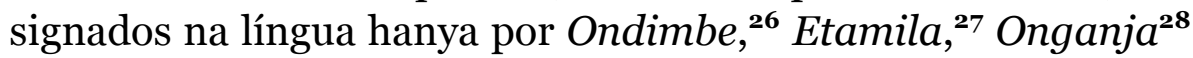
Ekwambo ${ }^{29}$ e Ondilwa. ${ }^{30}$

A presença do óleo de palma é indispensável, usado para ungir a bengala e a cadeira do soberano de forma a ter frescura e beleza, procedimento conhecido entre os Vahanya por okuvaveka.

Também a manteiga (ongundi), usada para manter a elegância das pessoas, que afluem a ombala, partindo do princípio de que todo o homem é elegante se tiver a pele lisa e amolecida. E, finalmente, o mel que representa o sabor das palavras do soberano. Parte-se do princípio de que o soberano resolve os problemas de forma pacífica. Nas suas palavras está representado o sabor. Espera-se das palavras do soberano a sabedoria para a solução dos problemas da comunidade.

\subsection{O fim do ritual e o encontro com a comunidade}

O ritual de entronização termina com a unção dos anciãos conselheiros no peito ou na «boca» de estômago. Em seguida, coloca-se à disposição do soberano investido, o pirão ou funji feito de farinha de milho e carne cozida do boi sacrificado para a cerimónia que partilha com os anciãos e olosoma ${ }^{\mathbf{3}}$ presentes. O sacrificar um animal nos actos ritualistas é evidenciado por Connerton (1999:1), ao referir

$\mathbf{2 5}$ Instrumento de música usado pelos criadores de gado bovino que serve de companheiro da solidão durante o pasto.

26 Prato feito de barro, usado para servir com pirão para refeição.

27 Prato feito de artesanato, usado para servir pirão.

28 Caneca extraída de uma espécie de abóbora, usada para tomar água ou outro tipo de bebida.

29 Caneca extraída de uma espécie de abóbora, usada para servir água ou outro tipo de bebida.

30 Prato grande feito de artesanato usado para servir pirão, a partir do qual são servidos os pratos individuais (atamila, plural: etamila).

31 Plural de osoma, autoridade tradicional. 
que a celebração de muitos ritos requer a morte de um animal, por vezes a morte real ou simulada de um ser humano.

O soberano investido é conduzido para aldeia onde a multidão o aguarda com ansiedade, aos quais é apresentado. Inicialmente, o investidor apresenta o novo soberano ao representante máximo da administração do Estado aí presente e aos demais convidados. Trocam-se discursos entre as autoridades tradicionais e os membros do governo. Por um lado, a declarar preenchida a vacatura que existiu e agradecer os apoios prestados e, por outro, a agradecer a realização do acto que serviu de ajuda na resolução das lideranças das comunidades.

A realização do processo ritual é bastante significativa para as sociedades, não só para as ditas sociedades primitivas como também para as chamadas sociedades avançadas. É, segundo Turner (1968: 270), um sinal de unidade entre os que pretendem participar nesse processo.

O soberano investido, permanecendo sentado na sua cadeira especial com os meios simbólicos e os respectivos guardas, faz o primeiro pronunciamento para os presentes, entre convidados e a população. Começa então a verdadeira festa. Muita dança ocilumbonde do oñoma (batuque), muita bebida de diversas qualidades com destaque para owala, ${ }^{\mathbf{3 2}}$ elingenhe ${ }^{33}$ e comida diversas, um verdadeiro ambiente atractivo de festa que envolve as comunidades das olombala vizinhas, convidadas ou não, bastando a atracção do ambiente «festivo».

\section{Conclusão}

A entronização do rei de linhagem como processo ritual representa, tal como refere o antropólogo J. S. La Fontaine (1984), uma acção social, pelo facto de a sua realização depender da participação das pessoas sob a direcção de um líder ou de líderes. O ritual toma carácter social por ter um padrão moralmente correcto a ser seguido em qualquer comunidade tradicional. Daí, a existência de regras que determinam os indivíduos que devem participar e em que

32 Bebida fermentada feita de massambala ou de farelo de milho (cerveja).

33 Aguardente de primeira, fabricado em especial para a cerimónia (vinho, cerveja, etc.). 
momento. Por vezes, atribuindo-se extrema relevância às regras exclusivas do que às inclusivas sobre a participação.

As comunidades angolanas em geral e as dos Vahanya em particular, há já bastante tempo, têm sido impedidas de realizar as suas manifestações culturais como as de entronização de um soberano de linhagem, devido às interferências do Estado colonial e da religião, antes da Independência, e do esvaziamento do poder tradicional pelas autoridades do Estado pós-independência. "A colonização $e$ as ocupações tornaram o poder [tradicional] num instrumento de dominação, contrariando a faceta sublime do exercício do poder local» (MassuanganHe 2011: 113).

Alguns actos esporádicos de entronização realizados em determinadas partes do território nacional e os dois realizados na comunidade Vahanya abrem a perspectiva para a reposição do poder de linhagem, desde que o referido poder não continue a ser visto como uma ameaça para autoridades tradicionais que não são de linhagem, instituídas pelo Governo. Aliás, é o próprio governo que tem apelado ao resgate dos valores culturais que representam a identidade dos angolanos, sendo a entronização dos soberanos de linhagem, um deles.

\section{Referências bibliográficas}

BEATTIE John

1964, Other cultures. Methods and achievements in Social Anthropology. Londres, Chen \& West.

BonTe Pierre e Izard Michel

1991, Dictionnaire de l'Ethnologie et de l'Anthropologie. Paris, Presses Universitaires de France.

BOURDIEU Pierre

1982, "Les rites comme actes d'institution», em Actes de la Recherche en Sciences Sociales, vol. 43, Juin, pp. 58-63.

CONNERTON Paul

1999 (2. a edição), Como as sociedades recordam. Celta Editora. Disponível em <http://pt.scribd.com/doc/52960963/Paul-Connerton-Como-as-Sociedades-Recordam-1>, consultado em 25 de Abril de 2015.

EJIzo Christopher

1986 (1. ${ }^{\text {a }}$ edição), Ofo: Igbo ritual symbol. Enungu, Fouth Dimension Publishing Co., Ltd. 
FonTAINE J. S. La 1985, Initiation. Ritual drama and secret knowledge across the world. Edinburgh, Edinburgh University Library.

GenNEP Arnold Van

1978, Os ritos de passagem. Tradução de Mariano Ferreira. Petrópolis, Editora Vozes.

GuEBE António

2003, O que eu aprendi no Otchoto. Luanda, Kilombelombe [«O Cruzeiro do Sul»; 1].

HAUENSTEIN Alfred 1967, Les Hanya. Description d'un groupe ethnique Bantu de l’Angola. Wiesbaden, Franz Steiner Verlag.

MANN Peter $\mathrm{H}$.

1983 (4. ${ }^{\text {a }}$ edição), Métodos de investigação sociológica. Tradução de Octávio Alves Velho. Rio de Janeiro, Zahar Editores.

Massuanganhe Israel Jacob

2011, «O poder local, as autoridades tradicionais e a reforma da governação local: As relações do poder e os desafios no quadro da descentralização», Justiça do Direito, vol. I, n. ${ }^{\circ}$ 2, pp. 111-155 (edição especial). Disponível em <http://www.upf.br/seer/index. $\mathrm{php} / \mathrm{rjd} /$ article/viewFile/4006/2579>, consultado em 23 de Junho de 2015.

Quivy Raymond e CAMPENHOUdT Luc Van

1998 (2. ${ }^{a}$ edição), Manual de investigação em Ciências Sociais. Tradução de João Minhoto Marques, Maria Amália Mendes e Maria Carvalho. Lisboa, Gradiva.

REDINHA José

1974 (8. ${ }^{\text {a }}$ edição), Distribuição étnica de Angola. Luanda, Centro de Informação e Turismo de Angola.

REPÚBLICA DE ANGOLA

2010 (1. ${ }^{\text {a }}$ edição), Constituição da República de Angola, Luanda, Imprensa Nacional - E.P.

Pascoal Domingos

2003, Relacionamento entre o Estado e as Autoridades Tradicionais em Angola: O caso da Lunda-Sul (1975-1992). Dissertação para a obtenção do grau de Mestre em Estudos Africanos, Desenvolvimento Social e Económico em África: Análise e Gestão, Lisboa, ISCTE.- Instituto Superior de Ciências do Trabalho e da Empresa.

TURNER Victor

1968, The drums of affliction. A study of religious processes among the Ndembu of Zambia. Oxford, Clarendon Press e The International African Institute. 
WILSON Monica

1954, «Nyakyusa ritual and symbolism», American Anthropologist, new series, vol. 56, n. ${ }^{\circ}$ 2, part 1, pp. 228-241. Disponível em <http://www.jstor.org/stable/664361>, acessado em 12 de Novembro de 2014.

Recepção do manuscrito: 9/03/2016

Conclusão da revisão: 16/06/2016

Aceite para publicação: 30/06/2016

Title: The enthronement of the lineage sovereign in Angola: The case of the Hanya community

Summary: The present communication is themed Theenthronement of the sovereign «king» of lineage in Angola. The case of the Vahanya and is primarily aimed at, strengthening the policies of the Angolan government, in the rescue of cultural values, proceeding with a replacement of whatin the past, contributedto theunityand internal cohesionof Angolan traditional societies. Issues related to the subject of traditional authorities have been raised in variousworkshops, seminars and meeting in Angola. Traditional poweris a form of political power,usually exercised by the succession of a figure by family lineage, as it is usual in traditional African societies(and other parts of the world as well). Particularlyin Angola, the institutionalization of traditional power and the exercise of its authority obey to a form of social organization based on the family lineage, which can be matrilineal or patrilineal,there is, however, a tendency for patrilineal lineage to be the predominant, due to the gradual abolition of inheritance through maternal lineage. With the use of direct observation, interviewsand document analysisit was possible to obtain valuable elements that realize the importance of the enthronement ritual for a sovereign «king» of lineage in the ethnic subgroup Vahanya, which is known as an ethnic subgroup of the Ovimbundu.

Keywords: Traditional authorities, ritual, rite of passage.

\section{António Guebe}

É Licenciado em Ensino de História pelo Instituto Superior de Ciências da Educação (ISCED) do Lubango, província da Huíla, Angola e Mestre em Estudos Africanos, com especialização em Desenvolvimento social e económico em África: Análise e gestão pelo Instituto Superior de Ciências do Trabalho e da Empresa (ISCTE), Lisboa, Portugal e doutorando por essa mesma instituição. É pós-graduado em Eleições na Europa pelo Instituto de Ciências Sociais (ICS) da Universidade de Lisboa. Frequentou o Seminário metodológico de investigação em Ciências Sociais, organizado em Maputo pelo CODESRIA. Participou no projecto de investigação sobre «Um grupo etnolinguístico de Angola: Os Vahanya vistos por dentro», subvencionado pelo codesRia. Publicou, entre outros, os materiais seguintes: $O$ que eu aprendi no Otchoto (Luanda, Kilombelombe, 2003) e Resistência a ocupação colonial do 
Sul de Angola (1850-1917), na região dos Va-Nyaneka-Va-Nkhumbi e dos Va-Ambo (Luanda, Arte Viva, 2008); «Os provérbios na educação dos povos e sua integração no sistema de ensino: o caso dos Hanya», in Actas do III Encontro Internacional de História de Angola (Luanda, Arquivo Nacional de Angola, 2015, pp. 283-307).

[e-mail: aguebe@gmail.com]

\section{Domingos Pascoal}

É Licenciado em Ensino de História pelo Instituto Superior de Ciências da Educação (ISCED) do Lubango, província da Huíla, Angola e Mestre em Estudos Africanos, especialização em Desenvolvimento social e económico em África: Análise e gestão pelo Instituto Superior de Ciências do Trabalho e da Empresa (ISCTE), Lisboa, Portugal e doutorando pela Universidade de Évora, Évora, Portugal. Frequentou os seminários seguintes: A guerra colonial portuguesa, 1961-1970: Outras perspectivas e Como desenhar e defender a sua tese de doutoramento; participou no II Congresso de História contemporânea, que teve lugar em Évora; nos III e IV Encontro Internacional de História de Angola, que tiveram lugar em Luanda, Angola. Participou no projecto de investigação sobre «Um grupo etnolinguístico de Angola: Os Vahanya vistos por dentro», subvencionado pelo coDESRIA. Publicou «Reflexão sobre as minorias étnicas em Angola: O caso dos Mussuco (Suku)», in Actas do III Encontro Internacional de História de Angola. Luanda, Arquivo nacional de Angola, 2015, pp. 367-378.

[e-mail: pascoald@ymail.com] 